\title{
EXPLORING STUDENTS' ACADEMIC ACHIEVEMENTS IN ELECTRICITY AND MAGNETISM THROUGH LEARNING STYLES AND LEARNING STYLE-BASED INSTRUCTIONAL STRATEGIES IN MTHATHA HIGH SCHOOLS
}

\author{
Sakyiwaa Danso and Emmanuel Mushayikwa \\ University of the Witwatersrand, South Africa
}

\begin{abstract}
Recent studies of the teaching and learning process have shown that learners tend to receive and process information in different ways. This study was conducted to explore the impact of matching instructional strategies to the learners learning styles, considering their cultural background in the teaching of Electricity and Magnetism among Grade 11 physical science learners in schools around Mthatha. To achieve the intended objective and to answer the research question "what impact does the learners' learning style preferences have on learners' academic achievements", a total of 205 physical science learners were sampled for the study. A purposive convenience sampling technique was used to select four schools from the target population. A non-experimental quantitative exploratory design was adopted for the study. Physical Science Achievement Test and Index of Learning Style Questionnaire were the main instruments used for gathering the data. Data were analysed using descriptive statistics and inferential statistics including an independent sample ttest together with multiple regression analysis. The result indicates that, the four learning style categories combined did not contribute significantly to the academic achievement of the grade 11 learners in electricity and magnetism at the four high schools in Mthatha.
\end{abstract}

Keywords: Learning Styles, Instructional Strategies, Achievements, Physical Sciences

\section{Introduction}

The study of physical science as a subject at secondary school level has become a national priority in South Africa due to the growing awareness about its contributions to the socio-economic and technological development of the nation. Hence, the development of programmes to improve scientific literacy is currently an important endeavour in the South African educational context.

According to Larkin-Hein (2000) the brisk changes that continue to occur in academia suggest that learning should be a continuous process. Taber (2009) also posits that learning is a personal activity and each learner has to construct his or her own knowledge. However for learning to be personalised, McFarlane (2013) suggested that learners should develop an interest in the subject matter and construct new knowledge based on their understanding of the concepts, and more importantly, as Udo and Udofia (2014) affirmed, participate actively in the teaching and learning process. Therefore, according to Holbrook (2011) learners learn physical sciences to gain knowledge and skills as well as to pass in the subject knowledge examination.

In the learning environment, however, every learner has his/her own natural ways of acquiring and processing information. These unique ways are described by Singh, Govil and Rani (2015) as their learning styles. In literature numerous learning styles and learning style models exist due to the fact that learning is achieved at different levels. According to Zywno and Waalen (2002), learning style model classifies learners according to where they fit on a number of scales regarding the ways they receive and process information Hence, some 
theorists (for example Kolb, 1984) define learning styles by focusing on different aspects as observed by Akkoyunlu and Yilmaz-Soylu (2009).

In the same way, instructional strategies also vary. According to Felder (1988), some teachers teach by demonstrating, others by lecturing; while others emphasise on principles and applications. Therefore, how much a learner learns in a classroom is often due to the learners' inherent ability and prior preparation as well as the match between the learners' learning styles and the teacher's instructional strategies. However, there is also a general agreement that the most effective learning occurs when the learning activities are closely matched to the learners' preferred learning styles (Gordon and Bull, 2004). Gordon and Bull (2004) further stated that, by matching instructional strategies to the learners' learning style preferences; the learning process becomes easy and comfortable for both teacher and the learners. However, sometimes, mismatches occur; and as a result, some learners may get bored or discouraged and may perform poorly in examinations.

Vita (2001) claims there is another factor: the importance of cultural background in the development of individual learning style. This is supported by the fact that culturally-based educational experiences predispose individuals to certain ways of learning. This is reiterated by New York State Board of Regent's Report (1987, as cited in Claxton, 1990, p.3), "learning styles and behavioural tendency do exist and that learners from particular socialisation and cultural experiences possess preferences to knowledge that are highly functional in the indigenous home environment and can be capitalised upon to facilitate performance in academic settings". Knowing each individual learner's cultural background is essential preparation for facilitating and structuring successful instruction for all learners, as Hewson (1988) suggested, science teaching and learning should be culturally sensitive, giving attention to what is really happening in the learners' minds and hearts. As such, Guild (1994) recommends the selection of appropriate instructional strategies that match learners' learning style preferences and cultural attributes to facilitate smooth delivery and effective achievement of instructional objectives.

Some studies (for example, Mashile, 2001; Mji \&Makgato, 2006) in South Africa have investigated and reported on different factors that particularly affect the teaching and learning of physical sciences. These include; out-dated teacher-centred instructions and mismatches of teachers' teaching styles and learners' learning styles, among others. In their conclusion, they indicated that the recurring poor performance in the subject calls for a concerted effort for measures that will help improve the status quo.

Mji \& Makgato (2006) carried out their study in the Eastern Cape and reported that science teachers still used out-dated teacher-centred teaching strategies. The researchers' own experiences as science teachers in Mthatha also support this observation where traditional teacher-centred instruction emphasises the passive acquisition of knowledge. The bulk of the work involves teacher-talk, using either a lecture method or a simple question-andanswer technique that basically demands recall of knowledge from the learners, as observed by Zakaria and Iksan (2007). As noted by Kulkarni and Klemmer (2012), a severe deficiency in traditional teaching methods in the physical sciences resides in the fact that learners do not visualise the details of different science processes and they frequently fail to understand the most basic science concepts and phenomena.

Furthermore, one of the fundamental principles upon which the National Curriculum Statement (NCS) is based is the relevance of what is being learned. The NCS physical sciences curriculum structured content knowledge into six core areas (DoE, 2011). According to Chabay and Sherwood (2006), Electricity/Magnetism is one core area which learners perceived to be complex as it involves abstract and multidimensional phenomena that learners have difficulty comprehending. For example, in the sub-topic of electrostatics, electric fields and their associated representational formalisms are three-dimensional, abstract, and have few analogies to learners' everyday experience, as observed by Furio and Guisasola (1998). As a result, Chambers and Andre (1995) noted that, learners have trouble understanding the relationship of abstractions about electric fields to 
phenomenological dynamics. Therefore, to meet this need, Chinn and Samarapungavan (2009) recommended the use of different teaching strategies to cater for the different learning styles learners bring to the science classroom. Although, much research have been conducted on learning styles and their determinants, much less research seems to have been done on the learning style preferences among learners and their relationship to the embedded cultural context and further, how teachers can use this information to diversify the way they teach to engage all learners in a multicultural settings.

Against this background, the study investigated the impact of matching instructional strategies with the learners learning styles, considering learners cultural backgrounds in the teaching of the topic of Electricity and Magnetism to Grade 11 learners in schools around Mthatha. This paper is therefore reporting on a small part of a bigger study comprising both quantitative and qualitative research components.

\section{Purpose and Research Questions}

Specifically, the study was designed to identify learning style preferences among learners in Grade 11 and to explore the effectiveness of different learning style-based instructional strategies on learners' academic achievements in the concepts 'Electricity and Magnetism', considering learners' cultural background. Therefore, the following research questions were developed and served as the guiding force of the study.

1. What are the prevailing learning style preferences among grade 11 physical science learners based on the index of learning style questionnaire?

2. What impact does the learning style preference of learners have on their academic achievements?

\section{Review of the Literature}

The literature offers a myriad of definitions of learning styles and learning style models. As noted by Vita(2001), the one which, by virtue of its encompassing properties, still commands benchmarking significance, is that provided by Keefe (1979, p.4), that "learning styles are characteristic cognitive, effective, and psychological behaviours that serve as relatively stable indicators of how learners perceive, interact with, and respond to the learning environment". Accordingly, Schmeck (2013) defined learning style, as being the cognitive style that a person demonstrates or manifests when confronted with a learning task. Schmeck (2013) later expanded his definition of learning style to include concepts that incorporate individual motives and personal experiences that influence perception. However, Cassidy (2004) stated explicitly that the ideal way in which an individual approaches a learning situation has been characterized by a variety of theoretical learning style models. One such an ideal model is the Curry 'Onion' model (Curry, 1983).

The Curry's "Onion" Model is a standard method of classifying learning style models, which categorises learners learning differences as layers of an onion, with four layers: instructional preferences, social interaction preferences, information processing and personality levels (Coffield, Moseley, Hall, \& Ecclestone, 2004). The outermost layer comprises Instructional preferences which focus on the most observable traits of a learner, examples of which are emotional, and environment (Gordon \& Bull, 2004). Rezler (2013) and, Dunn and Dunn model (Dunn \& Dunn, 1993) of learning styles come under this category. Social interaction provides the next layer and relates to the ability of learners to interact with their peers in the learning process, as well as the differences related to gender, age or maturation levels. An example of this type of model is the Grasha and Riechmann (1975) type model. The innermost layer encompasses Cognitive Personality Style, which can shape and influence a learner's ability to acquire and integrate information. The Myers-Briggs Type Indicator (MBTI) is based on personality levels (Cuthbert, 2005).The more stable layer encompasses information processing model which is conceived as the individual's intellectual approach to obtaining information, sorting, storing and utilizing information (Gordon \& Bull, 2004). Learning style models such as; Kolb (1984); Schmeck, Ribich and Ramanaiah (1977) and Felder-Silverman (1988) learning style model fall under this category. 
The Felder-Silverman's model is one of the theoretical frameworks used to determine the different learning style preferences among people. Felder-Silverman (1988) defined learning style as the characteristics, strengths and preferences in the way people receive and process information. The model specifically focuses on the aspects of learning styles in engineering students (Kanninen, 2008) and describes the learning style of a student in four dimensions (Felder \& Henriques, 1995). We have specifically selected the Felder-Silverman's model as the pedagogical model for instructions in the physical sciences against competing alternatives for this study for the reason that it has been explicitly developed for classroom application and, provided a richer and more flexible sliding scales support for classifying the learners learning styles. Besides, it has a wide-ranging system of learning styles which help teachers to be more aware of the needs of the learners and adjust their instructions accordingly. The model has also been successfully implemented in previous studies on learning style and academic achievement of high school learners in science subjects (the most recent of which were: Adkins \& Guerreiro, 2017; Akinbobola, 2015).

The Felder-Silverman Learning Style (1988) model rates the learners' learning style in a scale of four dimensions; processing, perception, input and understanding. The first dimension (processing) distinguishes between an active and a reflective way of processing information. Active learners learn best by working actively with the learning material, by applying the material, and by trying things out. Reflective learners prefer to think about and reflect on the content. The second dimension (perception) distinguishes between sensing and intuitive learning. Sensing learners like to learn from facts and solve problems with standard approaches. In contrast, Intuitive learners prefer to learn from abstract materials and are more able to discover possibilities and relationships. The third dimension (input) focuses on the visual-verbal aspect. Visual learners remember best from every details of what they see and therefore prefer to learn from pictures and diagrams while verbal learners learn best from spoken materials and textual representations. The fourth dimension distinguishes between sequential and global dimension (understanding). Sequential learners learn in small incremental steps as they have a linear learning progress and tend to follow logical stepwise paths in finding solutions. In contrast, Global learners use a holistic thinking process and absorb learning material almost randomly without seeing connections but after they have learned enough materials they suddenly get the whole picture.

With the above in mind, the review of related studies have also shown that, all learners have different learning style preferences and that excellent teaching requires diagnosing the learning style of each learner and aligning teaching strategies accordingly (Kolb, 1984; Felder-Silverman, 1988; Dunn \& Dunn, 1993). A significant number of studies have been carried out to establish whether learning style preferences have any influence on learners' academic achievement. Jahanbakhsh (2012) investigated the relationship between learning styles of girls and their academic achievements based on their majors in Iranian high schools. The results indicated that Sensing/Intuitive learner's showed a significant correlation with the academic achievement of students whose major was mathematical science. In contrast, Gakhar (2006) studied the academic achievement of students as determined by their preferred learning styles, thinking styles and study skills. The results of the study showed no significant difference in the academic achievement of students with different learning styles. Therefore, the studies by Gakhar (2006), showed conflicting result from the study conducted by Jahanbakhsh (2012).

However, Pashler, McDaniel, Rohrer, and Bjork (2009) in their study concluded that in order for the learning styles "meshing hypothesis" (the matching, or meshing, hypothesis implies that students' learning is enhanced when a mode of instruction is used that matches their learning preference) to be confirmed, numerous welldesigned studies would have to test the matching hypothesis and show significant interaction effects. Therefore, Cuevas (2015) contends that it is not enough for research to simply show that students may have preferences for certain modes of learning because studies on metacognition have consistently shown that students' preferences and evaluation of their own learning tend to be highly inaccurate when compared to actual learning. Cuevas (2015) further stated explicitly that, consistent, replicable evidence of achievement is necessary to justify the effort required to implement learning style-based instructions. Accordingly, Mayer (2011) argues that learning styles research have persistently lacked rigor and that there is no evidence that clearly supports the application or practice of learning style-based instructions. In addition, Cuevas (2015) argued vehemently that much literature have been written on learning styles, but very little of it contributes to evidence-based support for the concept. However, we contend that, the development of learning style-based instructional tools could allow for easy 
creation of educational materials that take into cognisance learners learning style preferences and cultural background in the teaching/learning process to counter these critiques, and to give learners the opportunity to identify their learning styles in a new way to improve their achievement in science.

\section{Materials and Methods}

The study espoused the positivism worldview, to gather essential information numerically utilising quantitative exploratory approach, because the researcher aims at exploring the impact of learning style-based instructions on learner achievement by considering learners' cultural backgrounds. This phenomenon is therefore, multifaceted and required multiplicity of knowledge sources which were blended with the research questions to construct a meaningful proposition about the complex environment of learning styles and learning style-based instructions on achievement of learners in schools in Mthatha. The population of the study consisted of all grade 11 physical science learners in high schools in Mthatha. Purposive convenient sampling technique was employed to select four schools from the target population. A total of 205 learners and 4 physical science teachers participated in the study in their intact classes. The participating teachers were trained on the development and implementation of learning style-based instructions in the physical science classroom.

\section{Instrumentation}

Felder-Silverman Index of Learning Style Questionnaire (FSILSQ) and Physical Science Achievement Test (PSAT) were the main instruments used to gather data for this study.

The FSILSQ was adopted from Felder and Silverman (1998) learning style model. Permission to use the questionnaire was granted by the authors. The questionnaire was designed to assess and determine learners' learning style preferences on a scale of four dimensions and consisted of 44 forced-items with options ' $a$ ' and ' $b$ ' corresponding to one or the other category of the dimension. The learners were required to choose options that apply more to their learning styles, as each option refers to any of the four dimensions of the learning style including; active/reflective, sensing/intuitive, visual/verbal, and sequential/global. Scoring is done by summing up the number of ' $a$ ' and ' $b$ ' responses respectively for each dimension, with scores ranging from 1 to 11 . To obtain the total scores for each dimension, lower scores in each column are subtracted from the higher scores of either ' $a$ ' or ' $b$ ' and the difference determines the learning style of that learner. For example, a score of 9a under Active column and $2 b$ under the Reflective column will give a difference of $7 \mathrm{a}$ which indicates that the learner has a moderate preference for active learning. A learner's profile is therefore said to be low or mild (a score of 13 ), moderate (a score of 5-7) or strong (a score of 9-11) for one dimension on the scale.

Reliability tests were performed for each of the learning-style dimensions to ensure that the instrument was applicable to the South African population. Cronbach's alpha ranged from 0.73 to 0.78 . Reliability scores were therefore deemed fairly high and satisfactory, as confirmed by Felder and Spurlin (2005).

The PSAT consisted of 50 multiple choice items in the concept of electricity and magnetism, which were constructed by the researchers. Each item on the PSAT had four options; 'A', 'B', 'C', 'D' with only one correct answer, which was awarded 2 marks. The PSAT was validated by three physical science teachers, including the subject advisor of the district.

\section{Data Analysis}

The quantitative data were entered into SPSS and Microsoft Excel spreadsheet for data analysis. For research question 1, to determine the prevailing learning styles, descriptive statistics were employed. In addition, inferential statistics were employed to determine if there were any significant differences between learners' learning style-based instructions and learners' academic achievement to answer research question 2. Multiple regressions were employed to help determine how Felder-Silverman's learning and teaching styles (independently and in combination) measured learners' academic achievement in the physical sciences. A confidence interval of 0.05 was employed throughout the study therefore a $p$-value above 0.05 suggested that there was no significant difference between the learning style dimensions and the level of academic achievement in physical science. 
Sakyiwaa Danso and Emmanuel Mushayikwa/Exploring Students' Academic Achievements in Electricity and Magnetism Through Learning Styles and Learning Style-Based Instructional Strategies in ...

\section{Results and Discussions}

\section{Learners' learning style preferences}

The Table 1 highlights the distribution of learners across the four main dimensions of the Felder-Silverman's learning style: processing (active/reflective), perception (sensing/intuitive), input (visual/verbal), and understanding (sequential/global) used in this study.

Table 1: distribution of learning style preferences among the grade 11 physical science learners in Mthatha

\begin{tabular}{|c|c|c|c|c|c|c|c|}
\hline \multirow{2}{*}{\multicolumn{2}{|c|}{$\begin{array}{l}\text { Felder- Silverman Leaning } \\
\text { style dimensions }\end{array}$}} & \multicolumn{4}{|c|}{$\begin{array}{c}\text { Learners' distribution of learning style } \\
\text { dimensions by school level }\end{array}$} & \multicolumn{2}{|c|}{ TOTAL } \\
\hline & & \multirow{2}{*}{$\begin{array}{c}\begin{array}{c}\text { School } \\
\text { A }\end{array} \\
36 \\
\end{array}$} & \multirow{2}{*}{$\begin{array}{c}\text { school } \\
\text { B }\end{array}$} & \multirow{2}{*}{$\begin{array}{c}\text { School } \\
\text { C } \\
39 \\
\end{array}$} & \multirow{2}{*}{$\begin{array}{c}\text { School } \\
\text { D } \\
22 \\
\end{array}$} & \multirow{2}{*}{$\begin{array}{c}\mathbf{n} \\
127\end{array}$} & \multirow{2}{*}{$\begin{array}{c}\% \\
61,95 \\
\end{array}$} \\
\hline \multirow{3}{*}{ Processing } & Active & & & & & & \\
\hline & Reflective & 22 & 25 & 15 & 16 & 78 & 38,05 \\
\hline & Total & 58 & 55 & 54 & 38 & 205 & 100 \\
\hline \multirow{3}{*}{ Perception } & Sensing & 49 & 44 & 44 & 35 & 172 & 83,9 \\
\hline & Intuitive & 9 & 11 & 10 & 3 & 33 & 16,1 \\
\hline & Total & 58 & 55 & 54 & 38 & 205 & 100 \\
\hline \multirow{3}{*}{ Input } & Visual & 33 & 41 & 38 & 28 & 140 & 68,29 \\
\hline & Verbal & 25 & 14 & 16 & 10 & 65 & 31,71 \\
\hline & Total & 58 & 55 & 54 & 38 & 205 & 100 \\
\hline \multirow{3}{*}{ Understanding } & Sequential & 39 & 36 & 39 & 30 & 144 & 70,24 \\
\hline & Global & 19 & 19 & 15 & 8 & 61 & 29,76 \\
\hline & Total & 58 & 55 & 54 & 38 & 205 & 100 \\
\hline
\end{tabular}

From a total number of 205 respondents in the processing learning style category, 127 of them representing $62 \%$ were classified as active learners, forming the majority of this category, while 78 representing $38 \%$ were considered as reflective learners. Considering the perception learning style category, $33((16 \%)$ of the learners were classified as being intuitive, while $172(84 \%)$ were sensory, with the sensory forming the majority. A total of $65(31.7 \%)$ of the learners were considered as verbal while the majority of $140(68.3 \%)$ were identified as having a preference for visual under the input category of learning style. For the understanding learning style category, majority of the learners were sequential with $144(70.2 \%)$ of the learners, while $61(29.8 \%)$ of the learners were global. The table further illustrates that the predominant learning styles among the 205 respondents were Active (62\%); Sensing (68\%); Visual (68\%) and Sequential (70\%). This finding corroborates with those of Gonzales, Glaser, Howland, Clark, Hutchins, Macauley, and Ward, (2017) who determined the learning style preferences among nursing students to be more active, sensing, visual and sequential. This result shows that people have preferences in terms of how information is received and processed by each individual in the learning environment.

\section{Learning style preferences and academic achievement}

Learners' academic achievement for this study was assessed by the administration of a multiple choice test on electricity and magnetism. This topic was taught by four teachers from the four high schools who implemented learning style-based instructional strategies in their classrooms to teach electricity and magnetism. The academic achievement scores within each learning style dimension is described statistically using means, standard deviations and variances and estimated region for the location of the true mean at $95 \%$ confidence interval mean and presented in the sections that follow. 
Table 2: comparison of academic achievement in electricity and magnetism based on the learning style preferences of the grade 11 physical sciences learners

\begin{tabular}{|c|c|c|c|c|c|c|c|c|}
\hline \multirow{3}{*}{\multicolumn{2}{|c|}{$\begin{array}{l}\text { Learner's learning style } \\
\text { dimensions }\end{array}$}} & \multirow[t]{3}{*}{$\begin{array}{c}\text { Number } \\
\text { of } \\
\text { learners }\end{array}$} & \multirow{2}{*}{\multicolumn{3}{|c|}{ 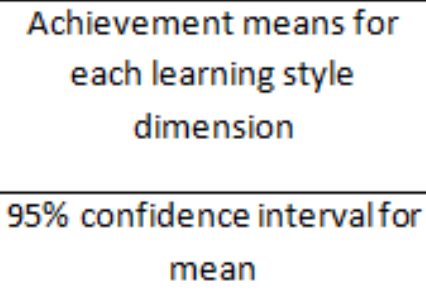 }} & \multirow{2}{*}{\multicolumn{2}{|c|}{$\begin{array}{l}\text { Standard } \\
\text { deviation and } \\
\text { variance }\end{array}$}} & \multirow[t]{3}{*}{ Skewness } \\
\hline & & & & & & & & \\
\hline & & & $\begin{array}{l}\text { Lower } \\
\text { bound }\end{array}$ & $\begin{array}{l}\text { Upper } \\
\text { bound }\end{array}$ & Mean & SD & Variance & \\
\hline \multirow[t]{2}{*}{ Processing } & Active & 127 & 61.66 & 65.27 & 63.5 & 10.27 & 105.55 & -0.39 \\
\hline & Reflective & 78 & 62.78 & 68.04 & 65.4 & 11.66 & 135.91 & -0.18 \\
\hline \multirow[t]{2}{*}{ Perception } & Sensing & 172 & 62.52 & 65.90 & 64.2 & 11.22 & 125.85 & -0.29 \\
\hline & Intuitive & 33 & 61.09 & 67.27 & 64.2 & 8.71 & 75.84 & 0.14 \\
\hline \multirow[t]{2}{*}{ Input } & Visual & 140 & 61.56 & 65.06 & 63.3 & 10.46 & 109.74 & -0.27 \\
\hline & Verbal & 65 & 63.29 & 68.95 & 66.1 & 11.42 & 130.36 & -0.32 \\
\hline \multirow[t]{2}{*}{ Understanding } & Sequential & 144 & 62.36 & 65.83 & 64.1 & 10.53 & 110.84 & -0.25 \\
\hline & Global & 61 & 61.48 & 67.43 & 64.5 & 11.61 & 134.85 & -0.27 \\
\hline
\end{tabular}

The Table 2 shows that, the mean for academic achievement scores of grade 11 active/reflective learners were 63.5 and 65.4 respectively. The Table 2 also shows that at 95\%confidence interval, the lower and upper bound for the true mean of academic achievement was 61.66 and 65.27 for active learners and 62.78 and 68.04 for reflective learners. This suggests that the probability of finding the location of the true score at 95 percent confidence interval for both active and reflective learners was within a similar region of distribution of their academic achievement scores. Furthermore, the Table 2 shows that the measure of standard deviation for the spread of academic achievement scores for active learners was 10.27 and reflective learners were 11.66. This measure of standard deviation indicates that the distribution of scores was nearly the same for both active and reflective learners.

Similarly, the mean for academic achievement scores of sensing learners were 64.2 and intuitive learners were 64.2. At $95 \%$ confidence interval, the lower and upper bound of the true mean of measures of academic achievement score was 62.52 and 65.90 for sensing learners, and 61.56 and 65.06 for intuitive learners and the measure of standard deviation for the distribution of academic achievement scores was 11.22 for sensing learners and 8.71 for intuitive learners. This further suggests that the distribution of academic achievement scores of sensing learners were relatively more dispersed than academic achievement scores of intuitive learners.

Moreover, the mean of academic achievement scores was 63.3 for visual learners and 66.1 for verbal learners. In addition, the Table 2 shows that, at 95 percent confidence interval, the lower and upper bound for the true mean of academic achievement scores of visual learners was 61.56 and 65.06 respectively and verbal learners was 63.29 and 68.95. This means that the probability of finding the location of the true score at $95 \%$ confidence interval for both visual and verbal learners was almost within same region of distribution of scores. Moreover, the Table 2 shows that the measures of standard deviation of the distribution of academic achievement scores were 10.46 for visual learners and 11.42 for verbal learners. This demonstrates that the distribution of academic achievement for both visual and verbal learners were comparable. 
Furthermore, the mean of academic achievement scores was 64.1 for sequential learners and 64.5 for global learners. In addition, at 95 percent confidence interval, the lower and upper bound for the true mean of academic achievement scores of sequential learners were 62.36 and 65.83 and global learners were 61.48 and 67.43. This means that the probability of finding the location of the true score at 95 percent confidence interval for both sequential and global learners was almost within same region of distribution of scores. Moreover, the result shows that the measures of standard deviation about the distribution of academic achievement scores were 10.53 for sequential learners and 11.61 for global learners. This demonstrates that the distribution of academic achievement for both sequential and global learners were approximately comparable.

Table 2 illustrates that there was no statistically significant difference between learners' academic achievement scores and any of the dimensions of learning style preferences among grade 11 physical science learners.

\section{Combined Effect and Relative Contribution of the Learning styles on Academic Achievement}

Table 3: Combined effect of learning style categories on academic achievement

\section{R: 0.146}

$R^{2}: 0.021$

Adjusted R square: 0.002

Std. error of the estimate: 10.826

ANOVA

\begin{tabular}{|l|c|c|c|c|c|}
\cline { 1 - 4 } Model & Sum of Squares & Df & Mean square & F & Sig. \\
\cline { 1 - 4 } Regression & 508.735 & 4 & 127.184 & & \\
\cline { 1 - 4 } Residual & 23438.660 & 200 & \multirow{2}{*}{117.193} & \multirow{2}{*}{1.085} & \multirow{2}{*}{0.365} \\
\cline { 1 - 4 } Total & 23947.395 & 204 & & & \\
\hline
\end{tabular}

The combination of the four learning style dimensions accounted for $2.1 \%$ of the variance $\left(\mathrm{R}^{2}: 0.021 ; \mathrm{p}: 0.365\right)$. Table 3 therefore suggests that statistically the four learning style dimensions combined do not contribute significantly to the academic achievement of the grade 11 learners in electricity and magnetism at the four high schools. 
Table 4: Relative contribution of learning styles on the level of academic achievement

\begin{tabular}{|c|c|c|c|c|c|c|c|c|c|}
\hline \multirow{2}{*}{ Model } & \multicolumn{2}{|c|}{$\begin{array}{l}\text { Unstandardised } \\
\text { coefficients }\end{array}$} & \multirow{2}{*}{$\begin{array}{c}\begin{array}{c}\text { Standardised } \\
\text { coefficients }\end{array} \\
\text { Beta }(\beta)\end{array}$} & \multirow{2}{*}{$t$} & \multirow{2}{*}{ Sig. } & \multicolumn{2}{|c|}{$\begin{array}{c}\text { 95\% Confidence } \\
\text { interval for B }\end{array}$} & \multicolumn{2}{|c|}{$\begin{array}{c}\text { Collinearity } \\
\text { statistics }\end{array}$} \\
\hline & B & Std. error & & & & $\begin{array}{l}\text { Lower } \\
\text { bound }\end{array}$ & $\begin{array}{l}\text { Upper } \\
\text { bound }\end{array}$ & Tolerance & VIF \\
\hline 1 (Constant) & 58.291 & 4.320 & & 13.494 & 0.00 & 49.772 & 66.809 & & \\
\hline Active/Reflective & 1.769 & 1.571 & 0.079 & 1.126 & 0.262 & -1.329 & 4.867 & 0.982 & 1.018 \\
\hline Sensing/Intuitive & -0.561 & 2.078 & -0.019 & -0.270 & 0.787 & -4.659 & 3.536 & 0.980 & 1.020 \\
\hline Visual/Verbal & 2.687 & 1.639 & 0.116 & 1.639 & 0.103 & -0.545 & 5.919 & 0.983 & 1.017 \\
\hline Sequential/Global & 0.451 & 1.658 & 0.019 & 0.272 & 0.786 & -2.818 & 3.719 & 0.995 & 1.005 \\
\hline
\end{tabular}

Results from Table 4 shows that the highest contributing learning style dimension to the achievement in electricity and magnetism was the visual/verbal category $(\beta=-0.116)$. Therefore, the contribution of the other learning style dimensions to the academic achievement in electricity and magnetism include active/reflective $(\beta=0.079)$ sequential /global $(\beta=0.019)$, and sensate/intuitive $(\beta=-0.019)$. Table 4 also shows that the Tolerance values of active/reflective (.982), sensing/intuitive (.980), visual/verbal (.983) and sequential/global (.995) were way above 0.1 . Hence, according to Leech, Barrett and Morgan (2005), if the Tolerance value is less that $1-R^{2}$ (where $R^{2}$ is adjusted $R^{2}$ of the regression model) there may be a probability of existence of multicollinearity problem. However, in this study the adjusted $R^{2}$ was 0.002 and $1-R^{2}$ was 1.002 which was well above the least Tolerance value of 0.980 . This implies that there was no sign of probability for multicollinearity problems among the learning style categories.

\section{The Study Findings and Implications}

To answer research question 1 , this study found that there were more active learners compared to reflective learners. In addition, there were more sensing learners compared to intuitive learners. Also, there were more visual learners compared to verbal learners and lastly, it was found that there were more sequential learners compared to global learners. From the analysis of the FSILSQ, it was found that majority of the females have preferences for the active, sensory, visual and sequential learning style dimension, compared to males. However, from a general perspective, it can be inferred that regardless of the gender differences, majority of the physical sciences learners prefer to perceive information in both forms of active, sensing, visual and sequential learning style categories.

To answer research question 2 which investigated the impact of learning style preferences on learners' academic achievement in electricity and magnetism, it was found that the average marks in the pre-test and post-test were 33 and 64 respectively indicating a 93\% increase in the average marks after the intervention. From the confidence interval value, we are $95 \%$ confident that the mean difference in the marks obtained by the learners before and after the intervention programme is between 29.97911 and 33.00129 . Based on this $95 \%$ confidence interval, we can conclude that there was a difference in the marks obtained by the learners after the intervention programme since the confidence interval for the mean difference does not include zero.

In order to establish the relationship and observe the degree of association between learning style preferences and academic achievement among the respondents, significance tests were computed.

Furthermore, data of the study was further subjected to the Regression model fit test and the indices of the coefficient of determination ( $\mathrm{R}$ square) and ANOVA tests for $\mathrm{R}^{2}$ of the regression model were used to empirically answer the second research question. The regression test suggests that the total explanatory power of learning styles in explaining academic achievement in electricity and magnetism was small. This implies that 
there were other important instructional variables which could explain academic achievement than learning styles can do. In addition, the ANOVA model of Sensing/Intuitive, Visual/Verbal, Active/Reflective and Sequential/Global failed to significantly predict academic achievement of the PSAT, $F(4,200)=1.085$, $\mathrm{p}=0.365$. The outputs of the regression test showed that the prediction of grade 11 science learners $(F(4,200)=$ $1.085, \mathrm{p}=0.365$ ) academic achievement in electricity and magnetism from the linear combination of learning styles was not statistically significant. Therefore, the regression model has failed to demonstrate statistically significant prediction of variations in academic achievement from the different learning style preferences. Thus, statistically, the four learning style categories combined do not contribute significantly to the academic achievement of the grade 11 learners in electricity and magnetism at the four high schools in Mthatha.

In concluding the quantitative phase of the study, the researchers posit that there was not a particular learning style preference that helped learners to be successful in learning the concept "electricity and magnetism" considered in this study. Moreover, the empirical data of the quantitative part of the study failed to suggest a learning style model specific for physical science education, but learning styles can be used to identify trends of learning style preferences among learners to improve instructional strategies adopted by physical science teachers to improve learner achievement in the subject.

The findings of this study therefore, have implications for teacher development and learner achievements. It is of vital importance that science teachers are exposed to varied instructional approaches of which they could implement in their science classrooms to accommodate learners with different learning style preferences to enhance learner achievement in the subject.

\section{Limitation and Future Research}

This study utilised a small sample size of 205 learners from a large population of physical science high school learners across South Africa and that can hinder the generalisation of the results. Limited studies in this field have been done in South Africa. Therefore, there is a great scope of research in the field of science education and in the broader field of education in general. The quantitative design utilised in this study could identify prevailing learning style preferences and their correlations with academic achievements, ignoring other aspects of learning that might hinder learner achievement. A mixed methods design could be utilised to create a healthy debate to get learners perceptions and conceptions about learning styles and learning style-based instructions in order to investigate the interactions and interrelationships between the main variables of the study.

\section{Recommendations}

It is recommended that more research should be done with the focus on learning style preferences and learner achievement among high school learners, taking other variables like cultural influence on learning style into consideration. This would provide substantial evidence about the role learning style-based instructions play in learner achievement in physical sciences. Furthermore, a necessity for studies interrogating learners' learning styles and teachers' instructional strategies and how these can be adjusted in order to increase learner achievement in physical science. Further studies could consider the issue of gender, race, and ethnicity in relation to learning style preferences and academic achievements among high school science learners.

\section{References}

Adkins, D. and Guerreiro, M., 2017. Learning styles: Considerations for technology enhanced item design. British Journal of Educational Technology.

Akinbobola, A. O., 2015. Effects of learning styles and instructional strategies on students' achievement in Nigerian senior secondary school physics. Advances in Physics Theories and Applications, 41(1).

Akkoyunnlu, B., and Yilmaz, S., 2009. "The effect of learning styles on achievement in different learning environment". TOJET: The Turkish Online Journal of Educational Technology, 8(4). Retrieved from: http://www.search.proquest.com.

Cassidy, S., 2004. Learning styles: An overview of theories, models, and measures. Educational Psychology. An International Journal of Experimental Educational Psychology.24 (1), 419-444.

Chabay, R., and Sherwood, B., 2006. Restructuring the introductory electricity and magnetism course. American Journal of Physics, 74(4), 329-336. 
Chambers, S.K., and Andre, T., 1995. Are conceptual change approaches to learning science effective for everyone? Gender, prior subject matter interest and learning about electricity. Contemporary educational psychology, 20 (4), pp. 377 - 391.

Chinn, C. A., and Samarapungavan, A. L. A., 2009. Conceptual change - multiple routes, multiple mechanisms: A commentary on Ohlsson (2009). Educational Psychologist, 44(1), 48-57.

Claxton, C.S., 1990. Learning styles, minority stu dents and effective Education. Journal of Developmental Education, 14 (1), 6.

Coffield, F., Moseley, D., Hall, E., and Ecclestone, K., 2004. Learning styles and Pedagogy in post 16 learning: A systematic and critical review. The Learning and Skills Research Centre: London.

Cuevas, J., 2015. Is learning styles-based instruction effective? A comprehensive analysis of recent research on learning styles. Theory and research in Education, 13(3), pp.308-333

Curry, L., 1983. An Organization of Learning Styles Theory and Constructs.

Cuthbert, P.F., 2005. The student learning process: learning styles or learning approaches. Teaching in Higher Education, 10(2), pp.235-249.

Department of Education. (2011). National Curriculum Statement Grades R - 12: Curriculum and Assessment Policy (CAPS) Physical Sciences. Pretoria: Department of Education. South Africa.

Dunn, R. S., and Dunn, K. J., 1993. Teaching secondary students through their individual learning styles: Practical approaches for grades 7-12. Prentice Hall.

Felder, R.M., 1988, October. How students learn: Adapting teaching styles to learning styles. In Frontiers in Education Conference, 1988., Proceedings (pp. 489-493). IEEE.

Felder, R.M. and Henriques, E.R., 1995. Learning and teaching styles in foreign and second language education. Foreign language annals, 28(1), pp.21-31.

Felder, R. M., and Silverman, L. K., 1988. Learning and teaching styles in engineering education. Engineering Education, 78(7), 674-681.

Felder, R. M., and Spurlin, J., 2005. Applications, reliability and validity of the index of learning styles. International journal of engineering education, 21(1), 103-112.

Furio, C. and Guisasola, J., 1998. Difficulties in learning the concept of electric field. Science Education, 82(4), pp.511-526.

Gakhar, M.,2006. A study of academic achievement as determined by their preferred learning, thinking styles and study skills. Psycho Lingua, 36(2).

Gonzales, L.K., Glaser, D., Howland, L., Clark, M.J., Hutchins, S., Macauley, K., Close, J.F., Leveque, N.L., Failla, K.R., Brooks, R. and Ward, J., 2017. Assessing Learning Styles of Graduate Entry Nursing Students as a Classroom Research Activity: A quantitative research study. Nurse Education Today, 48, pp.55-61.

Gordon, D., and Bull, G., 2004. The Nexus explored: A generalised model of learning styles. SITE 2004, Atlanta, Georgia, USA, March.

Grasha, A. F., and Riechmann. S. W. 1975. Student learning styles questionnaire. University of Cincinatti, Faculty Resource Center, Cincinatti, $\mathrm{OH}$.

Guild, P., 1994. The Culture/Learning Style Connection. Educational Leadership, 51(2), 16-21.

Hewson, M. G., 1988. The ecological context of knowledge: implications for learning science in developing countries. Journal of Curriculum Studies, 20, 317-326. 
Sakyiwaa Danso and Emmanuel Mushayikwa/Exploring Students' Academic Achievements in Electricity and Magnetism Through Learning Styles and Learning Style-Based Instructional Strategies in ...

Holbrook, J., 2011. Enhancing scientific and technological literacy (STL): A major focus for science teaching at school. Journal of Science. Teach. Assoc. Niger, 46(1):9-34.

Jahanbakhsh, R., 2012. Learning styles and academic achievement: A case study of Iranian high school girls' students. Procedia-Social and Behavioural Sciences, 51, 1030-1034.

Kanninen, E., 2008. Learning styles and e-learning. Master of Science Thesis, Tampere University of Technology.

Keefe, J. W., 1979. Learning style: An Overview. In Keefe, J W(Eds.) Student Learning Styles: Diagnosing and prescribing programs, NASSP, Reston.

Kolb, D.A., 1984. Experiential learning: Experience as the source of learning and development. Englewood Cliffs, NJ: Prentice Hall.

Kulkarni, C., and Klemmer, S.R., 2012. Learning design wisdom by augmenting physical studio critique with online self-assessment. Technical report, Stanford University.

Larkin-Hein, T., 2000. Learning styles in introductory physics: Enhancing student motivation, interest and learning. Paper presented at the international Conference on Engineering and Computer Education. August 2000. Sao Paolo, Brazil (pp. 1-6).

Leech, N. L., Barrett, K. C., and Morgan, G. A., 2005. SPSS for intermediate statistics: Use and interpretation (2 ed.). Mahwah, New Jersey: Lawrence Erlbaum Associates, Inc.

Mashile, E.O., 2001. Science achievement determinants: factorial structure of family variables. South African Journal of Education, 21(4), pp.336-338.

Mayer, R.E., 2011. Does styles research have useful implication for educational practice? Learning and individual Differences, 21 (3), 319 -320.

McFarlane, D. A., 2013. Understanding the challenges of science education in the 21st century: New opportunities for scientific literacy. International Letters of Social and Humanistic Sciences, 4(1), 35-44.

Mji, A., and Makgato, M., 2006. Factors associated with high school learners' poor performance: a spotlight on mathematics and physical science. South African Journal of Education, 26(2), 253-266.

Pashler, H., McDaniel, M., Rohrer, D., and Bjork, R., 2009. Learning styles: Concepts and evidence. Psychological Science in the Public Interest 9(3): 105-119.

Rezler, A. G., 2013. Learning Preference Inventory. Journal of Clinical Reasoning \& Procedural Competency, 1(1), 31-47.

Schmeck, R. R., Ribich, F., and Ramanaiah, N., 1977. Development of a self-report inventory for assessing individual differences in learning processes. Applied Psychological Measurement, 1(3), 413-431.

Schmeck, R. R. (Ed.), 2013. Learning strategies and learning styles. Springer Science \& Business Media.

Singh, L., Govil, P., and Rani, R., 2015. Learning Style Preferences among Secondary School Students. International Journal of Recent Scientific Research, 6(5), 3924-3928.

Taber, K.S., 2009. Learning from experience and teaching by example: reflecting upon personal learning experience to inform teaching practice. Journal of Cambridge Studies, 4 (1), 82-9.

Udo, M. E., and Udofia T, M., 2014. Effects of mastering learning strategy on students' achievement in symbols, formulae and equations in chemistry. Journal of Educational Research and Reviews, 2(3), 28-35

Vita, G. D., 2001. Learning styles, culture and inclusive instruction in the multicultural classroom: A business and management perspective. Innovations in Education and Teaching International, 38(2), 165-174. 
Proceeding of the $3^{\text {rd }}$ International Conference on Education, Vol. 3, 2017, pp. 64-76

Zakaria, E., and Iksan, Z., 2007. Promoting cooperative learning in science and mathematics education: A Malaysian perspective. Online Submission, 3(1), 35-39.

Zywno, M.S., and Waalen, J.K., 2002. The effect of individual learning styles on students' outcomes in technology-enabled education. Global Journal of Engineering Education, 6(1), 1-10. 